SSHRC Research Network

New Approaches to

Lifelong Learning

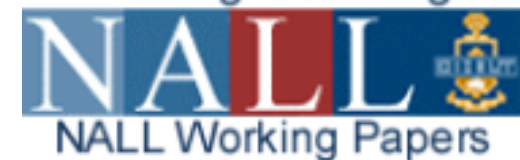

\title{
Whatever Happened to Yesterday's Rebels? Longitudinal Effects of Youth Delinquency on Education and Employment
}

By Julian Tanner, Scott Davies and Bill O'Grady

WALL Working Paper No. 5, 1999 


\begin{abstract}
This paper examines whether and how teen delinquency is consequential for a variety of educational and employment outcomes. From the National Longitudinal Survey of Youth we measure five forms of delinquency from 1979 when respondents were 14-17 years old, and investigate whether they predict five different outcomes when those individuals were aged 25-30. We measure delinquency as the prevalence of skipping school, drug use, violent behavior, engaging in property crime, and contact with the criminal justice system. Using a variety of regression models, we explore whether delinquency has negative zero-order effects, and negative partial effects net of standard status attainment variables. We find that all types of delinquency have consistently significant and negative impacts on educational attainment among both males and females, net of status attainment variables. Delinquency has also a fairly consistent impact on male occupational outcomes, but has weaker effects on female occupational outcomes. Overall, the data suggests that delinquency has autonomous and negative effects on later life chances. We discuss these findings in light of links between Status Attainment models and theories of crime and delinquency.

What happens in young adulthood to those who were rebellious, delinquent, or resistant during their youth? Does teenage delinquency tend to spoil adult outcomes, or alternatively, is it a mere passing phase with few long term consequences? And what do these outcomes tell us about the meaning of youthful deviance? In this paper we pursue empirically these questions by focusing upon educational and occupational attainments, and explore whether there are direct or indirect links between juvenile misconduct, educational success, and adult occupational attainment.
\end{abstract}

\title{
Status Attainment and Delinquency: Good and Bad Capital Investments
}

To explain school and occupational achievement, status attainment models originally employed a host of individual background, social psychological, and educational variables (see Sewell and Hauser, 1980). More recent research has shown how, in addition, disciplined work habits, cultural capital, social capital and parental involvement in their children's education all aid attainment net of social background and measured school ability (e.g. Farkas et al.,1990; Schneider and Coleman, 1993; Aschaffenburg and Maas, 1997).

The metaphor of "capital” speaks to a process whereby various forms of cultural and social activity in one's early years later pay off by bettering one's life chances, and helping to smooth the transition from school to the labor market. Conversely, other forms of cultural activity do the opposite: they can depreciate such investments. Delinquency is one such potential source of capital disinvestment. Life-style choices and indiscretions that range from tardiness and indiscipline, to delinquency or criminality, we argue, can harm attainments and create cumulative, long term disadvantage. Moreover, they can have this effect independent of one's resources, economic or cultural. A recent study by Alexander, Entwisle and Horsey (1997), for instance, found that poor attitudes 
and undisciplined behavior among children in the first grade had a strong impact on eventual school success, net of family background and measures of academic standing and ability (ie. grades and test scores).

Such a finding can be construed as offering a mirror-image of what Status Attainment researchers have discovered. A key contribution of American applications of Bourdieu's (1984) ideas about the import of cultural capital is to show that its effects upon achievement cannot be reduced to class origins, as measured by parental socioeconomic background (DiMaggio, 1982; Aschaffenburg and Maas, 1997). Similarly, the future capital disinvestments associated with delinquency may also be independent of the present economic and cultural endowments of one's parents. We aim to test if delinquency has a long and deleterious reach. Our premise is that the scope of educational and occupational attainment models can be enhanced by looking at the barriers in adolescence to attainments in adulthood. Research on social stratification and crime and deviance has been, until recently, relatively uncoupled (Hagan, 1991; but see also Crutchfield and Pitchford, 1997). Typically, Status Attainment research focuses upon the conformist endeavors of adults, whereas students of delinquency concentrate on the miscreant activities of youth. Our task in this paper is to help further bridge these two research worlds by incorporating measures of teenage delinquency into attainment models.

\section{Sociological Images of the Long Term Impact of Delinquency:}

Classic sociological images of the long term impact of teenage delinquency differ sharply. On the one hand, Subcultural theorists, beginning with Albert Cohen (1955), anticipate that deviance will eventually deliver rebellious (male) youth to the rough-end of the labor market. Paul Willis (1977) and Jay Macleod (1995) are the principle contemporary suppliers of this image of clear and predictable pathways from resistance in school to working-class jobs. Working-class boys get working-class jobs - the allimportant sub-title of Learning to Labour - because their celebratory rejection of middle class schooling, their repertoire of minor delinquency, and their masculinist bravado, all disqualify them for anything other than low-skill manual occupations. It is a fate, however, the "Lads" welcome as confirmation of their working class status and identity. MacLeod's ethnography, Ain't No Making It, travels similar terrain in an American context.

On the other hand, there is a tradition of sociological criminology which downplays the significance of teenage deviance, and counters what it sees as an overdeterministic portrayal of delinquency. The principal architect of this view, David Matza (1961), confronted Subcultural theory by emphasizing the essential similarities between most deviant behavior and conformity. By doing so, Matza downgraded the long-term significance of milder forms of teenage rule breaking. Indeed, he took his argument further and proposed that mainstream teenage culture functions as a safety valve for most pleasure-seeking adolescents by insulating them from more serious, and consequential, delinquency. Further, he accused the original Subculturalists of, variously, explaining more delinquency that actually occurs, exaggerating the class basis of delinquency, and 
of offering few clues as to why rebellion fades away as adulthood approaches. Willis and the newer "Resistance" school have been similarly accused of this type of overdeterminism (Tanner, 1996; Davies, 1995)

These diverging views of the severity of teenage deviance highlight the need to unravel the long-term effects of delinquency with systematic research. Influential as Willis, Macleod and Matza have become, they derive their alluring images from very small, unrepresentative samples, and in the case of Willis, without benefit of a follow-up study to verify the original argument. ${ }^{1}$ Whether or not high school delinquents fare poorly in school, and are ultimately relegated to low-status jobs or unemployment is an open empirical proposition that can only be tested with longitudinal data.

Further, there is the issue of gender. Early studies all but ignored female deviance, or treated it as a sexual, rather than a law and order, problem (Murdock, 1982; Frith, 1985). Accordingly, the classic images of rebellious or resistant youth rarely includes females (ie. those offered by Cohen, Matza, Willis and Macleod). An overweening concern with male rebellion and its consequences has forced the study of female deviance and its impact upon jobs to the sidelines. Our study compensates for this by including an examination of the effects of delinquency on jobs and education for both males and females. It thus stands apart from other studies, including some of the most prominent longitudinal ones (described further below), that concentrate exclusively upon male behavior and experiences (Sampson and Laub, 1993; Hagan, 1993; Freedman, 1992).

However, what might be expected from a separate analysis of males and female trajectories is a relatively open question. On the one hand, it can be argued that females will be less seriously damaged by earlier delinquent experiences than males. The recent, increasingly gender-sensitive, literature tells us that most of the important differences between female and male offenders relate to incidence and prevalence. Adolescent girls are less frequent offenders than boys; they more to likely desist from delinquent activity at an earlier age (Chesney-Lynn and Sheldon, 1992), and they are more likely to be deterred from further wrong-doing as a result of their initial contacts with police (Keane, Gillis, and Hagan, 1989). Similarly, female labor force participation rates have been traditionally lower than those of males - a reflection of the fact that female destinations are less intimately bound to employment outside the home than is the case for males. If delinquency is thus a less regular occurrence among adolescent females, and if paid employment outside the home has been until recently less central to the adult goals of young women, then it would be unreasonable to expect their lives to be as strongly governed by these activities. Furthermore, since women - no matter how well-endowed with human, cultural or social capital - enter a narrower range of jobs than men - it is correspondingly less likely that the cultural deficit of delinquency will leave an equivalent indentation upon female careers. As a result, we might expect female lifecourse trajectories to be less significantly marred by delinquency than those of males.

On the other hand, a case can also be made for the opposite outcome: that even though girls are less immersed with delinquency than boys, and abandon it more quickly, 
it may still be the case that the minority that do become involved suffer more in later life. Generally less inured to the idea of female deviance, society is particularly concerned with the control of female sexuality. Adolescent girls who do break to appropriate conduct norms may therefore anticipate problematic repercussions across a variety of adult domains, including work and employment.

Historical evidence certainly suggests that the police and courts have shown a greater interest in regulating the moral behavior of girls than boys. It is for such status offences as incorrigibility, truancy and moral deprivation that girls, rather more frequently than boys, have been referred to the juvenile court. Similarly, girls have often received harsher punishment, including institutional sentences, for violating moral codes than the criminal code (Reiss, 1960). And while girls may benefit more readily than boys from police discretion when criminal acts are involved, they have also been more frequently for infringements of status offences which often connote gender-specific undesirable sexual activity (Monahan, 1970). Overall, therefore, it seems that boys are punished more for illegal acts, whereas girls are more vulnerable to judicial concerns about moral propriety.

\section{Longitudinal Research on Delinquency}

Sociological research on education clearly shows that delinquency has negative and reciprocal associations with school grades and retention (Stinchcombe, 1964; Polk and Schafer, 1972; Myers, Baker, Milne, and Ginsburg, 1987; Mensch and Kandel, 1988; Davies, 1995). In turn, volumes of status attainment research attest to the overwhelming significance of educational success as a determinant of occupational success (Sewell and Hauser, 1980). Given this research, one might expect delinquents to eventually do less well in school compared to their more conformist peers, and to subsequently fare worse in the labor market. Schooling, in this view, would merely reinforce the corrosive effects initiated by delinquency.

But what about the effects of delinquency over the long haul? Criminology clearly shows that while most adult criminals have delinquent pasts, few teenage delinquents become adult criminals (Farrington, 1992; Rutter and Smith, 1995; Sampson and Laub, 1993). If few deviants grow into hard core criminals, youth deviancy may exert little negative impact on eventual status attainment. The fact that most adolescents in the general population grow out of delinquency suggests that it is not always strongly damaging in the long-term, and may have only a negligible effect upon occupational attainment.

Existing research on this issue, however, is incomplete, and does not offer a clear answer, since its findings tend to depend on the nature of the measures and samples used. For instance, when using measures of non-criminal or less serious forms of delinquency, such as deviant leisure or "party subcultures," some research supports Matza's image of inconsequential effects of teen deviance, or shows that the effects of this deviance are contingent upon other factors. Bynner and Ashford (1992), when examining teenage lifestyles in a longitudinal study of young people in Britain, found little evidence to 
suggest that subcultural activities predicted pathways into the labor market, and concluded that for the most part, adolescent leisure has an ephemeral quality. Hagan (1991) found that Toronto-area middle class males actually benefitted from engaging in a leisure-oriented, non-delinquent 'party' subculture.

Others focus on various contingencies. Monk-Turner (1989) argues that experiences of school success may break the connection between youth crime and subsequent occupational under-achievement, claiming that if delinquents do well in school, occupational future life-chances go un-threatened. Jessor et al's (1993) research on adolescents in the American mid-west found a continuity between adolescence and adulthood - the more problematic an individual's behavior during the former, the more problematic an individual's behavior throughout the latter - but also found that youthful deviance had no significant effect upon occupational attainment. They hold that the consequences of deviant behavior depend in part on one's social class background, since middle-class youngsters in well-heeled communities have access to resources - economic, social, cultural - that provide them with a safety-net when they 'get into trouble', and which protect them from suffering long-term consequences for their youthful indiscretions. Hagan (1991) found that the consequences of participation in various youth subcultures differed sharply by their class background.

Other studies, however, find broader and independent consequences of less savory forms of youthful deviance. Analyzing data originally collected by Sheldon and Eleanor Glueck (1950), Laub and Sampson (1994) found that childhood delinquents, compared to non-deviants, held weak educational, economic and professional aspirations, were more likely to be on welfare in both early and later adulthood, and were more likely to have an adult history of unstable employment. Hagan (1993), using a British sample of poor and working class Londoners, found higher rates of unemployment among former delinquents. He proposed that having delinquent friends and engaging in continuing delinquency leads to adult unemployment through the formation of a distinct social network that isolates individuals from legitimate employment opportunities.

Yet, the Gleuck's samples used by Sampson and Laub, as well as Hagan's London sample, are either of a clinical variety that consist of serious deviants, or are collected from relatively poor neighborhoods. Both types are overpopulated by those official delinquents who are most likely to be marred in later life by their adolescent indiscretions. ${ }^{2}$ Further, these samples are limited to small single towns or cities (ie. The Boston area for Sampson and Laub, a Toronto suburb for Hagan [1991], or a 1-mile radius of working class London (Hagan, 1993). Perhaps more importantly, many of these studies lack key control variables. In contrast, many new data samples are large and nationally representative, and offer the types of control variables needed to truly test for the independent effects of delinquency. For instance, none of the data sets reviewed above could objectively control for cognitive skill (as measured on a standardized test). This is key, since many delinquents' later school and labor market attainments may be harmed less by their deviant actions per se than by their lack of skills. This point has been made most forcefully in the work of Farkas (1996). 
Finally, the above-cited studies point to the importance of different measures of delinquency. Many offer either "mild” or non-criminal forms of delinquency, or only a single measure of "harder" delinquency. Since different forms of delinquency may have different impacts on life chances (a point discussed further below), studies that employ multiple measures of delinquency could help to better specify the links between deviance and resulting life chances.

\section{Research Questions}

We wish explore the theme of "whatever happened to yesterdays rebels" by examining whether and how teen delinquency, in terms of its total effects or its partial effects net of relevant variables, is consequential for a variety of adult educational and employment outcomes. The literature reviewed above, taken as a whole, suggests that the long term impact of adolescent deviance on various attainments still remains unclear. No one as yet has established whether teenage delinquency, measured in both "softer" and "harder" forms, has a clear causal link to adult attainments among a national, representative sample. The primary issue is what is the typical outcome, across the life course, caused by different forms of delinquency, independent of standard attainment variables, among a representative population. In this paper we are less concerned with the contingencies of these effects - ie, whether all groups of people are hurt in the same way or to the same degree - but whether or not most delinquents are hurt in some way. We explore bivariate models to inspect the total effects of delinquency on attainments, then explore multivariate models to inspect independent effects, and employ a series of interaction terms with SES and crime in order to explore some of these possible contingencies.

Our investigation can be placed also within the broader context of an ongoing debate within the criminological community about the relative import of personality characteristics and life events as influences upon adult attainments. On the one hand, there are those such as Goffriedson and Hirschi who claim that the trait of self-control acquired early in life and relatively invariant in its effects thereafter - is a strong determinant of both educational and occupational success and involvement in crime and delinquency. On the other hand, there is Sampson and Laub's life course argument which proposes that life events have an impact upon adult destinies that is not reducible to the motivational characteristics of individuals exposed to those life-turning events. The present paper is not a test of these different perspectives: we have no measure of Gottfredson and Hirschi's key explanatory variable, self control; and, more importantly, we do not share the axiomatic assumption that there are long term consequences of adolescent deviance. Indeed, our paper, in the first instance, is about establishing whether or not in a large representative sample (as opposed to smaller, less representative samples), there is a negative dividend for a misspent youth. Nevertheless, it is possible that the results of our inquiry will speak to the issues raised by these criminological protagonists.

To address our issues, we have made series of key decisions concerning our sample and measures. First, we have elected to test our hypotheses using a nationally 
representative sample of 14-17 year olds who were enroled in school in 1979. Our logic is to begin with a sample of students still in school, and then from that starting position trace the subsequent impact of their delinquency. This decision, of course, excludes any youth in that age range who had dropped out of school before that year. We have done so intentionally in order to focus on mainstream or "ordinary youth" (Brown, 1987), whether they be deviant and conformist. Relatively few American youth leave school at earlier ages, and those who do so are likely to be harder-core delinquents. This is important, since most of the contemporary influential theorizing about school resistance is based, lest we forget, on the activities of youth who were still in school at the time of each study. Willis' "lads" and Macleod's "Hallway Hangers" and "Brothers" were all full-time students, albeit reluctant ones, at their neighborhood public schools. Thus we are more interested in tracking the status outcomes of a broad swath of adolescent delinquents - about whom we know comparatively little - as opposed to documenting the under-performance of hard-core dropouts and street youth who are most likely to exhibit deviant and disadvantaged continuities over time (for such studies, see Hagan and McCarthy, 1992; McCarthy and Hagan, 1992; Tanner et al, 1995). By excluding the relatively anomalous, we can test the impact of delinquency upon relatively "typical" or ordinary high schoolers - the type of population examined by Status Attainment researchers. This also makes our statistical tests tougher and more conservative by eliminating the few most likely candidates for having long term effects of delinquency. (We ran the same models for the full sample; the results were entirely consistent with our broad conclusions based on the student sample.)

Second, model specification is crucial, since the effects of delinquency may be spurious if other key explanatory variables are not taken into account. To guard against this, our models include most predictors of schooling and job attainment used in standard school attainment and job attainment models. Unlike most studies in this area, we are able to control for background, school-related abilities, and cultural resources, and thus test with rigor for the existence of independent effects of delinquency. This allows us to see whether the adult legacy of youth deviance is a direct one, or is mediated through schooling. We also provide wide range of outcomes with multiple measures of educational and occupational outcomes in order to better capture the multi-dimensional nature of life chances.

Third, we have elected to examine a variety of separate, independent measures of delinquency, rather than a single, unitary scale of delinquency. (For statistical purposes we did examine models that included a single omnibus measure of delinquency, as is discussed in the Findings section.) While some criminologists hold that the effects of delinquency, in terms of sanction, stigma, and subsequent defiance (see Sherman, 1993) are more or less constant, it is unclear whether different forms of delinquency have different causes and consequences (c.f. Osgood, Johnston, O'Malley and Bachman, 1988). Hagan (1991), for instance, reported that different types of subcultural preferences had different consequences on subsequent life achievements. We thus believe it important to test whether or not all behaviors indulged by adolescents are equally harmful. Everyday experience, and the prescriptions of the criminal code, certainly suggest otherwise. Shoplifting from a corner store does not carry the same long-term 
consequences as wounding someone with a weapon. Rather than assume that all miscreant action produces the same effect, our concern is for seeing which particular forms of delinquent behavior are consequent for various life chances. Further, as described in the next section, our factor analyses were able to clearly separate different types of delinquency. We therefore examine five different types of delinquency, representing a range of severity, in order to test for their differential impact. Finally, to explore whether the connections between teen deviance and adult outcomes differ for males and females, we provide separate models for both men and women.

\section{Method}

We use the representative sample $(n=6,111)$ from the National Longitudinal Survey of Youth (NLSY79). This data set consists of an annual follow-up of youth aged 14-22 when initially interviewed in 1979. The NLSY. enjoys an excellent retention rate. By 1993, over $90 \%$ of original representative sample remained. To investigate the enduring impact of teen delinquency, we selected a subset of individuals: those still enrolled in school and between the ages of 14-17 in 1979, and examined the educational and employment outcomes for these individuals in 1990-1992, when they were 25-30 years of age. We exclude youth who had already dropped out of school for the reasons mentioned in the previous section, and because their inclusion would make unclear the causal connection between delinquency and some outcomes, since these youth's educational attainment would be largely determined from the outset.

This subset consists of 1,452 males and 1,397 females. Sample attrition between 1979 and 1992 and list-wise deletion of missing data reduces this sample to 1,145 males and 1,112 females for most models, yielding missing case rates of $21 \%$ and $20 \%$ respectively. These rates are very good for longitudinal data, and indeed they are better than virtually all other studies in this area of study. Most of our missing cases stem from missing data on a few select variables, especially father's occupation (used to calculate SES background), though some are due to sample attrition in later years. Samples are somewhat smaller for our models of occupational status, since many individuals, particularly females, were not in the labor force in 1992 ( $n=1,029$ for males; 917 for females). Since it is plausible that long-term delinquents may be over-represented among our missing cases, our tests are again conservative by being possibly biased against finding those effects that would support our thesis.

\section{Measures}

Our models include variables over a twelve-year span to afford a glimpse into the long-term impact of teen delinquency. Our main explanatory variables are five forms of teen delinquency. We constructed delinquency scales from the NLSY's retrospective questions pertaining to crime and deviance. In 1980, interviewees were asked to report their deviant activities over the previous year (the NLSY unfortunately lacks similar measures of crime and deviancy in later years). Using factor analysis and alpha reliability tests (tables available upon request), we created two single item variables and three scales by summing standardized scores of related survey items. ${ }^{3}$ Males and females 
had almost identical factor loadings, so we used the same scales for both males and females. Table 1 presents a summary of all variables.

The first variable is "skipping school", represented by a single question about the number of times over the previous year the respondent skipped school. Both common sense and previous research suggests to us that while skipping school ultimately depreciates achievements in the labor market, its effects will be most directly evident in educational attainments. While this item loaded with a series of questions regarding drug use, we decided to separate them in order to preserve their distinct theoretical meanings. The second variable is "drugs", which includes the number of times over the previous year the respondent drank alcoholic beverages, smoked marijuana or hashish, sold marijuana or hashish, and used other drugs. Standardized item alpha reliability for males $=.77$; for females, .74.

The third variable is "property crime", derived from the number of times in the previous year the respondent intentionally damaged property, shoplifted, stole items worth less than $\$ 50$ or more than $\$ 50$, knew someone who held or sold stolen property, and had broken into a building. Standardized item alpha reliabilities were .84 for males and .69 for females. The fourth variable is "violence", consisting of the number of times over the previous year the respondent used force to obtain things, seriously threatened someone, attacked someone with the intention of injuring them, or had fought at school or work. Standardized item reliabilities were .55 for males and .73 for females. We contend, (uncontroversially, we hope) that crimes against persons, crimes against property, and drug offenses represent different types of illegality. Criminal codes throughout much of the English-speaking world view interpersonal acts of aggression and violence as more morally wrong, and therefore more serious, than crimes against property. This hierarchy is reflected in sentencing dispositions. Our assumption is that engaging in forms of deviance that are generally agreed to be wrong and harmful, and which, upon apprehension, are severely responded to, will produce more negative long term consequences than participation in less serious wrong-doings. Drugs offenses are of course a slightly different story. There is considerably less consensus about the wrongfulness and harm caused by drug use - exemplified by periodic efforts to decriminalize marijuana. At the same time, much societal concern - in its extreme form, moral panic - centers on adolescent drug use. While the severity of responses to the drug problem may be out of proportion to its projected gravity, this should not obscure the fact that illicit substance use is a risky pleasure, carrying many potentially negative ramifications if discovered. In sum, we are using a variety of indicators of delinquency because of the varying levels societal response to different forms of delinquency; such varying responses, we argue, may well lead to differing effects of adult attainment.

We also added a fifth measure of delinquency. "Contact with criminal justice system" is a dummy variable that scores a value of one if the respondent had ever had any one of the following experiences by 1980: if they had ever been stopped by police, or booked, or charged, or convicted. While previous research has occasionally looked at the effects of these sorts of contacts, the follow-up periods have usually been very short (ie. within the teenage years; see Sampson and Laub, 1997). In contrast, we explore the 
effects of this variables across the adolescent-adult divide, and assume that the police and courts are most inclined to handle the most persistent and serious offenders. Adolescent encounters with the criminal justice system thus become, in the first instance, a proxy measure of respondent's own delinquent behavior. In addition, it is also possible that such encounters are, or will become, generative of adolescent dissent. Being stopped by police - no matter howl reasonable from the police view - may provoke a spirit of defiance and disrespect for authority that may make further offending more likely (Sherman, 1993). Farrington (1977) has demonstrated that subsequent to first conviction, English delinquents develop more aggressive attitudes towards the police. Similarly, those stoppages by the police that result in arrest and conviction, and thus receive official and public recognition as being criminal, provide a fertile breeding ground for labeling, the formation of deviant identities, and most concretely, reluctant hiring by employers.

Our expectations with respect to the effects of delinquency vary. At the bivariate level, we expect all forms of delinquency to have a negative impact upon school attainment, for both males and females. However, at the multivariate level, the more severe forms of delinquency, such as violence and property crime, may not be significant once key measures of background and cognitive skill are controlled. Those individuals most likely to engage in those crimes may come from the types of backgrounds (ie. low SES), or have the types of student profiles (ie. low standardized tests scores) that result in poor school attainments. Further, while we expect delinquency to be important in models of educational attainment, those effects could be weaker in models of occupational attainment for the simple reason that the later occur later in time, and are more distant from the occurrence of teenage delinquency.

Table 1: Variable Definitions and Descriptive Statistics

\begin{tabular}{|c|c|c|c|}
\hline Variable & Description & \begin{tabular}{|l|} 
Male \\
mean \\
$(\mathrm{sd})$ \\
$\mathrm{N}=1,144$
\end{tabular} & $\begin{array}{l}\text { Female } \\
\text { mean } \\
(\mathrm{sd}) \\
\mathrm{N}=1,112\end{array}$ \\
\hline SES & $\begin{array}{l}\text { Summed z scores of father's Duncan SEI score, father's and } \\
\text { mother's educational attainment when respondent was } 14\end{array}$ & $\begin{array}{l}.738 \\
(2.034)\end{array}$ & \begin{tabular}{|l|l}
.612 \\
$(2.041)$
\end{tabular} \\
\hline $\begin{array}{l}\# \text { of Siblings, } \\
1979\end{array}$ & & $\begin{array}{l}3.041 \\
(2.120)\end{array}$ & $\begin{array}{l}3.197 \\
(2.141)\end{array}$ \\
\hline $\begin{array}{l}\text { Two parent } \\
\text { family }\end{array}$ & $=1$ if lived with natural father and mother at age & \begin{tabular}{|l|l}
.853 \\
$(.354)$
\end{tabular} & $\begin{array}{l}.836 \\
(.370)\end{array}$ \\
\hline Age & Age Years of age in 1979 & $\begin{array}{l}15.550 \\
(1.055)\end{array}$ & $\begin{array}{l}15.629 \\
(1.063)\end{array}$ \\
\hline $\begin{array}{l}\text { African } \\
\text { American }\end{array}$ & If African American =1 & \begin{tabular}{|l|l}
.109 \\
$(.312)$
\end{tabular} & $\begin{array}{l}.114 \\
(.318)\end{array}$ \\
\hline Hispanic & If Hispanic =1 & $\begin{array}{l}.060 \\
(.238)\end{array}$ & $\begin{array}{l}.077 \\
(.267)\end{array}$ \\
\hline $\begin{array}{l}\text { Cultural } \\
\text { Resources }\end{array}$ & $\begin{array}{l}\text { Additive scale of whether anyone in respondent's household at } \\
\text { age } 14 \text { received magazines newspapers or owned a library card }\end{array}$ & $\begin{array}{l}2.268 \\
(.880)\end{array}$ & $\begin{array}{l}2.276 \\
(.900)\end{array}$ \\
\hline Cog. Skill & Percentile score on the AFQT & 46.993 & 45.753 \\
\hline
\end{tabular}


Yesterday's Rebels

\begin{tabular}{|c|c|c|c|}
\hline & & $(28.900)$ & $(26.826)$ \\
\hline $\begin{array}{l}\text { Educational } \\
\text { Expectations }\end{array}$ & $\begin{array}{l}\text { Highest grade respondent expects to complete, 1979, measured in } \\
\text { years }\end{array}$ & $\begin{array}{l}14.108 \\
(2.215)\end{array}$ & $\begin{array}{l}14.124 \\
(2.070)\end{array}$ \\
\hline $\begin{array}{l}\text { Highest grade } \\
\text { completed, '92 }\end{array}$ & Measured in years & $\begin{array}{l}13.348 \\
(2.377)\end{array}$ & $\begin{array}{l}13.409 \\
(2.244)\end{array}$ \\
\hline Skipped School & Number of days skipped in 1979 & $\begin{array}{l}1.335 \\
(1.507)\end{array}$ & $\begin{array}{l}1.246 \\
(1.390)\end{array}$ \\
\hline Drugs & $\begin{array}{l}\text { Summed z scores from 1979, self reported number of occurrences } \\
\text { in the past year: drank alcohol, smoked marijuana or hashish, used } \\
\text { other drugs, sold marijuana or hashish (standardized item alpha } \\
=.770 \text { for males, } .740 \text { for females) }\end{array}$ & $\begin{array}{l}-.054 \\
(3.703)\end{array}$ & $\begin{array}{l}.082 \\
(3.752)\end{array}$ \\
\hline Property Crime & $\begin{array}{l}\text { Summed z scores from } 1980 \text {; self report of number of times in the } \\
\text { past year the respondent had intentionally damaged property, stole } \\
\text { belongings worth less than } \$ 50 \text {, stole belongings worth more than } \\
\$ 50 \text {, shoplifted, broken into a building, knew someone who } \\
\text { held/sold stolen goods (standardized item alpha }=.837 \text { for males, } \\
692 \text { for females) }\end{array}$ & $\begin{array}{l} \\
-.117 \\
(4.259)\end{array}$ & $\begin{array}{l}.093 \\
(3.867)\end{array}$ \\
\hline Violence & $\begin{array}{l}\text { Summed } \mathrm{z} \text { scores from } 1980 \text {, self report of number of times the } \\
\text { respondent in the past year fought at school or work, used force to } \\
\text { obtain things, seriously threatened someone, and attacked someone } \\
\text { with the intention to injure (standardized item alpha }=.546 \text { for } \\
\text { males, .732 for females) }\end{array}$ & $\begin{array}{l}-.035 \\
(2.898)\end{array}$ & $\begin{array}{l}-.019 \\
(2.655)\end{array}$ \\
\hline $\begin{array}{l}\text { Contact with } \\
\text { criminal justice } \\
\text { system }\end{array}$ & $\begin{array}{l}\text { If ever one of the following: stopped by police, or booked, or } \\
\text { charged, or convicted by } 1980=1\end{array}$ & $\begin{array}{l}.298 \\
(.458)\end{array}$ & $\begin{array}{l}.103 \\
(.305)\end{array}$ \\
\hline $\begin{array}{l}\text { Occupational } \\
\text { status in } 1992\end{array}$ & Duncan SEI score & $\begin{array}{l}39.507 \\
(23.676)\end{array}$ & $\begin{array}{l}48.829 \\
(20.609)\end{array}$ \\
\hline $\begin{array}{l}\text { Unemployed in } \\
1990\end{array}$ & If unemployed for at least 1 week = 1 & $\begin{array}{l}.167 \\
(.373) \\
\end{array}$ & $\begin{array}{l}.156 \\
(.363)\end{array}$ \\
\hline $\begin{array}{l}\text { College graduate } \\
\text { in } 1992\end{array}$ & If highest grade completed is equal to 16 or more $=1$ & $\begin{array}{l}.252 \\
(.434)\end{array}$ & $\begin{array}{l}.248 \\
(.432)\end{array}$ \\
\hline $\begin{array}{l}\text { High School } \\
\text { diploma by } 1992\end{array}$ & If received a high school diploma or GED by $1992=1$ & $\begin{array}{l}.889 \\
(.314)\end{array}$ & $\begin{array}{l}.919 \\
(.273)\end{array}$ \\
\hline
\end{tabular}

Our control variables consist of social background and school measures that are pertinent to educational and occupational attainment. Background variables include SES, race, family structure, number of siblings, and cultural capital. SES is a composite of standardized scores for father's Duncan SEI, mother's education, and father's education (measured by years of schooling). Two dummy variables represent racial background: African American and Hispanic; the reference is non-black / non-Hispanic. Family structure was measured as a dummy variable where living in a two-parent household at age 14 was coded 1 , all other family arrangements coded 0 . Family size is a raw score of the respondent's number of siblings. We also add a measure of cultural resources, used by some researchers as an indicator of family-transmitted cultural capital (see Teachman 1987). This is a composite ranging from 0 to 3, derived from whether at age 14 the respondent's family subscribed to magazines, subscribed to newspapers, or owned a 
library card. This measure has been shown to predict various educational outcomes (Davies and Guppy, 1997).

A second block of independent variables consists of two academic measures which are pertinent to educational and occupational attainment and which are standard predictors of school outcomes in status attainment models. "Cognitive skill" is measured by the respondent's percentile score on the AFQT (which measures skill and knowledge in reasoning and language). Educational expectations is the number of years of schooling the respondent expected to eventually attain.

Our dependent variables consist of education and employment outcomes. Three educational outcomes represent differing levels of attainment by 1992: highest grade completed, whether the respondent ever received a high school diploma or GED, and whether they completed a college degree. Given that opportunities to return to school have greatly expanded in the past 20 years, these measures from 1992 offer a longer-term perspective than cross-sectional measures of dropping out or university attendance. For employment outcomes, we have two important indicators of life chances and conditions: respondent's Duncan SEI in 1992, and whether they were unemployed in 1990.

\section{Analysis}

Our statistical analysis proceeds in four stages. We commence with a series of bivariate regressions to measure gross effects of delinquency on educational and occupational attainment. We then introduce controls in three successive multivariate models that resemble status attainment models but that contain also delinquency variables. The first multivariate model examines the partial effects of each delinquency variable separately, controlling for background variables. The second model adds educational variables to those equations, while the final model incorporates all delinquency variables into the same equations in order to estimate the unique effects of the various forms of delinquency. For models of employment we add the variable "highest grade completed" to control for eventual educational attainment. Our statistical analysis consists of ordinary least square regressions for continuous dependent variables, and logistic regression for the dichotomous dependent variables.

\section{Findings}

Is delinquency related to educational and employment outcomes? Does delinquency have significant effects on attainment net of standard status attainment variables? Tables 2 and 3 presents regression coefficients for delinquency from three models for each dependent variable. Model one in each instance contains bivariate regression coefficients; model two consists of background variables and one delinquency variable, and model three consists of background variables, education variables, and one delinquency variable (in the latter two models only the partial coefficients for delinquency are presented for reasons of space). Each coefficient in models two and three represents a separate regression (ie. one that includes skipped school, then one that includes drugs, then property crime, etc). 
The upper panels of Tables 2 and 3 show that among both males and females, all forms of delinquency have a significantly negative impact on the three educational outcomes. Whether at the zero-order level (model 1), or controlling for background (model 2), or controlling for both background and education (model 3), each form of delinquency (with only a single exception) has a significant negative impact on each measure of educational attainment. Since the magnitudes of the delinquency coefficients are reduced very little upon the inclusion of background variables (and in some instance they grow), it does not appear that delinquents merely hail from the types of backgrounds that tend to produce unsuccessful students. Rather, the act of delinquency itself has a negative influence, over and above the demographic characteristics of the delinquent. Further, those negative influences persist even controlling for key student characteristics such as cognitive skill and educational expectations. Thus, delinquency does not merely reduce students' educational skills and aspirations, nor are youth with lower expectations and fewer skills merely more likely to be delinquent. Rather, delinquency exerts a penalty over and above one's academic characteristics. These findings thus confirm the contention that teenage delinquents, male and female, have lessened eventual outcomes in school.

There is, however, a more varied pattern of effects across the two employment outcomes, as shown in the lower panels of Tables 2 and 3. Among males, all forms delinquency have expected negative impacts on occupational status in bivariate models and models that control for background. For instance, whether or not one has contact with the criminal justice system reduces one's occupational status score by over seven points; each day reported of skipping school reduces those scores by over two points. However, when educational variables (including highest grade completed) are added in model 3, all delinquency coefficients are sharply reduced. Indeed, only drug use and property crime have significant direct effects on occupational status controlling for both background and education. These findings suggest that while some forms of delinquency have direct impacts on men's eventual job attainment, much of that impact is mediated through education.

Turning to the right-hand side of the lower panel of Table 2, all delinquency variables have significantly negative impacts on unemployment among males. Men's odds of being unemployed during 1990 were increased by involvement in all forms of delinquency in 1980, even controlling for background and education. Delinquency thus appears to create some insecurity in males' subsequent employment. Indeed, Table 2 suggests that for males, high school delinquency has effects that are felt twelve years later in both educational and occupational realms. ${ }^{4}$

Among females, however, the lower panel of Table 3 presents a somewhat different story. Female occupational status is barely affected by delinquency. ${ }^{5}$ The most noteworthy effect is found in model two, wherein contact with the criminal justice system hurts female occupational status scores by over five points. However, this effect drops to non-significance once educational variables are introduced in model three, suggesting that for females, the negative influence on delinquency on occupational status occurs largely through its hindrance on their educational attainment. This gender difference in 
effects can be explained in terms of women's continuing need to balance employment and familial obligations. Women, no matter how well qualified, are still less inclined than men to maximize their occupational aspirations - settling instead for less prestigious employment if it helps them make that reconciliation. If this is the case, delinquency would cause relatively lesser harm in the labor market.

Table 2: Estimates from Regressions of Dependent Variables on Delinquency, Males

\begin{tabular}{|c|c|c|c|c|c|c|c|c|c|}
\hline \multirow[b]{2}{*}{ Predictor } & \multirow{2}{*}{\begin{tabular}{|l|}
$\begin{array}{l}\text { Highest } \\
\text { by } 1992\end{array}$ \\
$\begin{array}{l}\text { Model } \\
\text { 1a }\end{array}$ \\
\end{tabular}} & \multicolumn{2}{|c|}{ Grade Completed } & \multicolumn{3}{|c|}{$\begin{array}{l}\text { High School Diploma by } \\
1992\end{array}$} & \multicolumn{3}{|c|}{ College Degree by 1992} \\
\hline & & \begin{tabular}{|l} 
Model \\
2b
\end{tabular} & \begin{tabular}{|l} 
Model \\
3c
\end{tabular} & & $\begin{array}{l}\text { Model } \\
\text { 2b }\end{array}$ & \begin{tabular}{|l|} 
Model \\
3c
\end{tabular} & \begin{tabular}{|l|} 
Model \\
1a
\end{tabular} & \begin{tabular}{|l} 
Model \\
2b
\end{tabular} & \begin{tabular}{|l|} 
Model \\
3c
\end{tabular} \\
\hline $\begin{array}{l}\text { Skipped } \\
\text { school }\end{array}$ & \begin{tabular}{|l}
$-.345^{* * *}$ \\
$(.042)$ \\
$\mathrm{n}=1,328$
\end{tabular} & \begin{tabular}{|l|}
$-3.24 * * *$ \\
$(.038)$ \\
$n=1,217$
\end{tabular} & $\begin{array}{l}-.208 * * * \\
(.032) \\
n=1,217\end{array}$ & $\begin{array}{l}- \\
.318^{* * *} \\
(.049) \\
n=1,329\end{array}$ & $\begin{array}{l}-.319 * * * \\
(.057) \\
n=1,218\end{array}$ & $\begin{array}{l}- \\
325^{* * *} \\
(.067) \\
\mathrm{n}=1,218\end{array}$ & $\begin{array}{l}-.323 * * * \\
(.053) \\
\mathrm{n}=1,328\end{array}$ & \begin{tabular}{|l}
$-.358 * * *$ \\
$(.067)$ \\
$n=1,217$
\end{tabular} & $\begin{array}{l}- \\
.269 * * * \\
(.076) \\
n=1,217\end{array}$ \\
\hline Drugs & $\begin{array}{l}- \\
.088 * * * \\
(.021) \\
\mathrm{n}=1,260\end{array}$ & $\begin{array}{l}-.137 * * * \\
(.019) \\
n=1,162\end{array}$ & $\begin{array}{l}.089 * * * \\
(.016) \\
n=1,162\end{array}$ & $\begin{array}{l}\quad \begin{array}{l}-.047 * \\
(.026) \\
n=1,261\end{array} \\
\end{array}$ & $\begin{array}{l}.099 * * * \\
(.029) \\
\mathrm{n}=1,163\end{array}$ & $\begin{array}{l}-.117 * * * \\
(.035) \\
n=1,163\end{array}$ & $\begin{array}{l}-.092 * * * \\
(0.25) \\
n=1,260\end{array}$ & \begin{tabular}{|l|}
- \\
$.174 * * *$ \\
$(.032)$ \\
$n=1,162$
\end{tabular} & $\begin{array}{l}.138 * * * \\
(.036) \\
n=1,162\end{array}$ \\
\hline $\begin{array}{l}\text { Property } \\
\text { crime }\end{array}$ & \begin{tabular}{|l}
$.050 * * *$ \\
$(.015)$ \\
$\mathrm{n}=1,258$
\end{tabular} & $\begin{array}{l}-.067 * * * \\
(.014) \\
n=1,161\end{array}$ & \begin{tabular}{|l|}
$-.041^{* * *}$ \\
$(.011)$ \\
$\mathrm{n}=1,161$
\end{tabular} & $\begin{array}{l}-.031 * \\
(.018) \\
n=1,259\end{array}$ & \begin{tabular}{|l||}
$-.041^{*}$ \\
$(.020)$ \\
$\mathrm{n}=1,162$
\end{tabular} & $\begin{array}{l}-.040^{*} \\
(.023) \\
\mathrm{n}=1,162\end{array}$ & $\begin{array}{l}-.063 * * * \\
(.019) \\
\mathrm{n}=1,258\end{array}$ & \begin{tabular}{|l}
$-.115 * * *$ \\
$(.026)$ \\
$\mathrm{n}=1,161$
\end{tabular} & \begin{tabular}{|l}
$-.090 * * *$ \\
$(.028)$ \\
$\mathrm{n}=1,161$
\end{tabular} \\
\hline Violence & $\begin{array}{l}- \\
104 * * * \\
(.022) \\
\mathrm{n}=1,280\end{array}$ & $\begin{array}{l}-.099 * * * \\
(.020) \\
n=1,182\end{array}$ & \begin{tabular}{|l}
$-.044^{* *}$ \\
$(.016)$ \\
$\mathrm{n}=1,182$
\end{tabular} & $\begin{array}{l}-.059 * * \\
(.025) \\
n=1,281\end{array}$ & \begin{tabular}{|l}
$-.070^{* *}$ \\
$(.030)$ \\
$n=1,183$
\end{tabular} & \begin{tabular}{|l}
-.036 \\
$(.034)$ \\
$\mathrm{n}=1,183$
\end{tabular} & $\begin{array}{l}-.137 * * * \\
(.030) \\
n=1,280\end{array}$ & \begin{tabular}{|l|} 
\\
$.144 * * *$ \\
$(.035)$ \\
$\mathrm{n}=1,182$
\end{tabular} & $\begin{array}{l}.092 * * \\
(-.038) \\
n=1,182\end{array}$ \\
\hline $\begin{array}{l}\text { Contact } \\
\text { criminal } \\
\text { justice }\end{array}$ & $\begin{array}{l}-.892 * * * \\
(.140) \\
n=1,302\end{array}$ & $\begin{array}{l}-.844 * * * \\
(.123) \\
n-1,203\end{array}$ & $\begin{array}{l}-.368 * * * \\
(.104) \\
n=1,203\end{array}$ & \begin{tabular}{|l}
$.824 * * *$ \\
$(.176)$ \\
$n=1,303$
\end{tabular} & $\begin{array}{l}-.874 * * * \\
(.202) \\
n=1,204\end{array}$ & $\begin{array}{l}-.602 * * \\
(.226) \\
n=1,204\end{array}$ & $\begin{array}{l}-.859 * * * \\
(.160) \\
n=1,302\end{array}$ & \begin{tabular}{|l}
- \\
$.998 * * *$ \\
$(.191)$ \\
$n=1,203$
\end{tabular} & \begin{tabular}{|l}
$-.647^{* *}$ \\
$(.222)$ \\
$\mathrm{n}=1,203$
\end{tabular} \\
\hline
\end{tabular}

Table 2 Estimates from Regressions of Dependent Variables on Delinquency, Males (cont'd)

\begin{tabular}{|c|c|c|c|c|c|c|}
\hline \multirow[b]{2}{*}{ Predictor } & \multicolumn{3}{|c|}{ Occupational Status 1992} & \multicolumn{3}{|c|}{ Unemployment in 1990} \\
\hline & Model 1a & Model 2b & Model 3c & Model 1a & Model 2b & Model 3c \\
\hline Skipped school & $\begin{array}{l}-2.139 * * * \\
(.449) \\
\mathrm{n}=1,188\end{array}$ & $\begin{array}{l}-1.818^{* * * *} \\
(.448) \\
\mathrm{n}=1,090\end{array}$ & $\begin{array}{l}-.465 \\
(.395) \\
n=1,090\end{array}$ & $\begin{array}{l}.169 * * * \\
(.047) \\
\mathrm{n}=1,248\end{array}$ & $\begin{array}{l}.152 * * \\
(.040) \\
\mathrm{n}=1,118\end{array}$ & $\begin{array}{l}.135^{* *} \\
(.053) \\
n=1,118\end{array}$ \\
\hline Drugs & \begin{tabular}{|l}
$-.889 * * *$ \\
$(.221)$ \\
$n=1,132$
\end{tabular} & $\begin{array}{l}.1 .140^{* * *} \\
(.219) \\
\mathrm{n}=1,044\end{array}$ & $\begin{array}{l}-.380 * * * \\
(.193) \\
n=1,044\end{array}$ & $\begin{array}{l}-.058 * * * \\
(.023) \\
n=1,189\end{array}$ & \begin{tabular}{l}
\multicolumn{1}{c}{$.091^{* * *}$} \\
$(.025)$ \\
$\mathrm{n}=1,069$
\end{tabular} & $\begin{array}{l}.086 * * * \\
(.025) \\
n=1,069\end{array}$ \\
\hline Property crime & \begin{tabular}{|l}
$-.674 * * *$ \\
$(.164)$ \\
$\mathrm{n}=1,131$
\end{tabular} & \begin{tabular}{|l}
$-.844 * * *$ \\
$(.164)$ \\
$\mathrm{n}=1,044$
\end{tabular} & \begin{tabular}{|l}
$-.470 * * *$ \\
$(.142)$ \\
$\mathrm{n}=1,044$
\end{tabular} & \begin{tabular}{|l|}
.026 \\
$(.016)$ \\
$\mathrm{n}=1,187$
\end{tabular} & \begin{tabular}{|l|}
$.042 * *$ \\
$(.018)$ \\
$n=1,069$
\end{tabular} & \begin{tabular}{|l}
$.037^{*}$ \\
$(.018)$ \\
$n=1,069$
\end{tabular} \\
\hline
\end{tabular}


Yesterday's Rebels

\begin{tabular}{|c|c|c|c|c|c|c|}
\hline Violence & $\begin{array}{l}-.897 * * * \\
(.241) \\
n=1,148\end{array}$ & $\begin{array}{l}-.871 * * * \\
(.240) \\
n=1,060\end{array}$ & $\begin{array}{l}-.187 \\
(.270) \\
n=1,060\end{array}$ & $\begin{array}{l}.050 * \\
(.024) \\
n=1,209\end{array}$ & $\begin{array}{l}.-057 * \\
(.026) \\
n=1,088\end{array}$ & $\begin{array}{l}.042 * \\
(.027) \\
n=1,088\end{array}$ \\
\hline Contact criminal justice & $\begin{array}{l}-7.211 * * * \\
(1.479) \\
n=1,169\end{array}$ & $\begin{array}{l}-7.295^{* * *} \\
(1.448) \\
n=1,080\end{array}$ & $\begin{array}{l}1.848 \\
(1.271) \\
n=1,080\end{array}$ & $\begin{array}{l}.485 * * * \\
(.156) \\
n=1,229\end{array}$ & $\begin{array}{l}.563^{* * *} \\
(.169) \\
n=1,1106\end{array}$ & $\begin{array}{l}.454^{* *} \\
(.174) \\
n=1,106\end{array}$ \\
\hline
\end{tabular}

Notes:

For highest grade completed and occupational status, cells contain unstandardized OLS coefficients; all other cells contain logistic regression coefficients. Standard errors are in parentheses.

$*$ denotes 1-tailed $\mathrm{p}<.05, \quad * * \mathrm{p}<.01, * * * \mathrm{p}<.001$

a Zero-order coefficients

b Partial coefficients controlling for SES, number of siblings, family type, age, African American, Hispanic, cultural resources

c Partial coefficients controlling for all variables in b and cognitive skill, educational expectations.

Table 3: Estimates from Regressions of Dependent Variables on Delinquency, Females

\begin{tabular}{|c|c|c|c|c|c|c|c|c|c|}
\hline \multirow[b]{2}{*}{ Predictor } & \multicolumn{3}{|c|}{$\begin{array}{l}\text { Highest Grade Completed } \\
\text { by } 1992\end{array}$} & \multicolumn{3}{|c|}{$\begin{array}{l}\text { High School Diploma by } \\
1992\end{array}$} & \multicolumn{3}{|c|}{ College Degree by 1992} \\
\hline & $\begin{array}{l}\text { Model } \\
\text { 1a }\end{array}$ & $\begin{array}{l}\text { Model } \\
2 \mathbf{b}\end{array}$ & $\begin{array}{l}\text { Model } \\
\text { 3c }\end{array}$ & $\begin{array}{l}\text { Model } \\
1 \mathrm{a}\end{array}$ & $\begin{array}{l}\text { Model } \\
2 b\end{array}$ & $\begin{array}{l}\text { Model } \\
3 c\end{array}$ & $\begin{array}{l}\text { Model } \\
\text { 1a }\end{array}$ & $\begin{array}{l}\text { Model } \\
2 \mathbf{b}\end{array}$ & $\begin{array}{l}\text { Model } \\
\text { 3c }\end{array}$ \\
\hline $\begin{array}{l}\text { Skipped } \\
\text { school }\end{array}$ & $\begin{array}{l}- \\
.249 * * * \\
(.044) \\
n=1,289\end{array}$ & $\begin{array}{l}2.33 * * * \\
(.041) \\
n=1,162\end{array}$ & $\begin{array}{l}- \\
.134 * * * \\
(.034) \\
n=1,162\end{array}$ & $\begin{array}{l}- \\
.287 * * * \\
(.063) \\
n=1,290\end{array}$ & $\begin{array}{l}-.315 * * * \\
(.072) \\
n=1,163\end{array}$ & $\begin{array}{l}- \\
.277 * * * \\
(.080) \\
n=1,163\end{array}$ & $\begin{array}{l}- \\
.284 * * * \\
(.056) \\
n=1,289\end{array}$ & $\begin{array}{l}- \\
.318 * * * \\
(.068) \\
n=1,162\end{array}$ & $\begin{array}{l}- \\
.262 * * * \\
(.079) \\
n=1,162\end{array}$ \\
\hline Drugs & $\begin{array}{l}-.053 * * \\
(.020) \\
n=1,232\end{array}$ & $\begin{array}{l}- \\
.101 * * * \\
(.018) \\
n=1,128\end{array}$ & $\begin{array}{l}- \\
.064 * * * \\
(.015) \\
n=1,128\end{array}$ & $\begin{array}{l}-.016 \\
(.032) \\
n=1,233\end{array}$ & $\begin{array}{l}-.080 * \\
(.036) \\
n=1,129\end{array}$ & $\begin{array}{l}-.086^{*} \\
(.039) \\
n=1,129\end{array}$ & $\begin{array}{l}- \\
.080 * * * \\
(0.24) \\
n=1,232\end{array}$ & $\begin{array}{l}- \\
.153 * * * \\
(.031) \\
n=1,128\end{array}$ & $\begin{array}{l}- \\
.121 * * * \\
(.034) \\
n=1,128\end{array}$ \\
\hline $\begin{array}{l}\text { Property } \\
\text { crime }\end{array}$ & $\begin{array}{l}-.041^{* *} \\
(.016) \\
n=1,228\end{array}$ & $\begin{array}{l}- \\
.051 * * * \\
(.015) \\
n=1,123\end{array}$ & $\begin{array}{l}-.034^{* *} \\
(.012) \\
n=1,123\end{array}$ & $\begin{array}{l}-.056 * * \\
(.019) \\
n=1,229\end{array}$ & $\begin{array}{l}-.068 * * * \\
(.021) \\
n=1,124\end{array}$ & $\begin{array}{l}-.068 * * \\
(.025) \\
n=1,124\end{array}$ & $\begin{array}{l}-.049 * \\
(.022) \\
n=1,228\end{array}$ & $\begin{array}{l}- \\
.093 * * * \\
(.031) \\
n=1,123\end{array}$ & $\begin{array}{l}-.097 * * \\
(.035) \\
n=1,123\end{array}$ \\
\hline Violence & $\begin{array}{l}- \\
.135^{* * * *} \\
(.024) \\
n=1,241\end{array}$ & $\begin{array}{l}- \\
.088^{* * * *} \\
(.022) \\
n=1,135\end{array}$ & $\begin{array}{l}-.037 * \\
(.018) \\
n=1,135\end{array}$ & $\begin{array}{l}- \\
.117^{* * *} \\
(.028) \\
n=1,242\end{array}$ & $\begin{array}{l}-.109 * * * \\
(.031) \\
n=1,136\end{array}$ & $\begin{array}{l}-.074^{*} \\
(.035) \\
n=1,136\end{array}$ & $\begin{array}{l}- \\
.182 * * * \\
(.043) \\
n=1,241\end{array}$ & $\begin{array}{l}-.117^{* *} \\
(.045) \\
n=1,182\end{array}$ & $\begin{array}{l}-.087 * * \\
(-.045) \\
n=1,135\end{array}$ \\
\hline $\begin{array}{l}\text { Contact } \\
\text { criminal } \\
\text { justice }\end{array}$ & $\begin{array}{l}- \\
.505 * * * \\
(.207) \\
n=1,265\end{array}$ & $\begin{array}{l}- \\
.726 * * * \\
(.186) \\
n-1,155\end{array}$ & $\begin{array}{l}-.389 * * \\
(.154) \\
n=1,155\end{array}$ & $\begin{array}{l}-.662^{* *} \\
(.277) \\
n=1,266\end{array}$ & $\begin{array}{l}- \\
1.112^{* * *} \\
(.320) \\
n-1,156\end{array}$ & $\begin{array}{l}-.732 * \\
(.360) \\
n=1,156\end{array}$ & $\begin{array}{l}-.474^{*} \\
(.244) \\
n=1,265\end{array}$ & $\begin{array}{l}-.805^{* *} \\
(.286) \\
n=1,155\end{array}$ & $\begin{array}{l}-.652 * \\
(.337) \\
n=1,155\end{array}$ \\
\hline
\end{tabular}


Yesterday’s Rebels

Table 3: Estimates from Regressions of Dependent Variables on Delinquency, Females(cont'd)

\begin{tabular}{|c|c|c|c|c|c|c|}
\hline \multirow[b]{2}{*}{ Predictor } & \multicolumn{3}{|c|}{ Occupational Status 1992} & \multicolumn{3}{|c|}{ Unemployment in 1990} \\
\hline & Model 1a & Model 2b & Model 3c & Model 1a & Model 2b & Model 3c \\
\hline Skippsd School & $\begin{array}{l}-.597 \\
(.469) \\
n=1,060\end{array}$ & $\begin{array}{l}-659 \\
(.478) \\
n=961 \\
\end{array}$ & $\begin{array}{l}-.195 \\
(.453) \\
n=961\end{array}$ & $\begin{array}{l}.005 \\
(.056) \\
n=1,228\end{array}$ & $\begin{array}{l}(.062)^{-.032} \\
n=1,091\end{array}$ & $\begin{array}{l}-.049 \\
(.063) \\
n=1,091\end{array}$ \\
\hline Drugs & $\begin{array}{l}-.206 \\
(.206) \\
n=1,015\end{array}$ & $\begin{array}{l}-.557 * * \\
(.207) \\
n=933\end{array}$ & $\begin{array}{l}-.228 \\
(.197) \\
\mathrm{n}=933\end{array}$ & $\begin{array}{l}.018 \\
(.025) \\
n=1,177\end{array}$ & $\begin{array}{l}.026 \\
(.026) \\
n=1,058\end{array}$ & $\begin{array}{l}.022 \\
(.027) \\
n=1,058\end{array}$ \\
\hline Property crime & $\begin{array}{l}-.222 \\
(.178) \\
n=1,010\end{array}$ & $\begin{array}{l}-.303^{*} \\
(.173) \\
\mathrm{n}=928\end{array}$ & $\begin{array}{l}-.169 \\
(.163) \\
\mathrm{n}=928\end{array}$ & $\begin{array}{l}.021 \\
(.018) \\
n=1,176\end{array}$ & $\begin{array}{l}.010 \\
(.021) \\
n=1,079\end{array}$ & $\begin{array}{l}.010 \\
(.021) \\
n=1,079\end{array}$ \\
\hline Violence & $\begin{array}{l}-.475^{*} \\
(.267) \\
n=1,021\end{array}$ & $\begin{array}{l}-.272 \\
(.265) \\
n=938\end{array}$ & $\begin{array}{l}-.077 \\
(.249) \\
\mathrm{n}=938\end{array}$ & $\begin{array}{l}.039 \\
(.027) \backslash \\
n=1,187\end{array}$ & $\begin{array}{l}.033 \\
(.028) \\
n=1,065\end{array}$ & $\begin{array}{l}.027 \\
(.029) \\
n=1,065\end{array}$ \\
\hline Contact criminal justice & $\begin{array}{l}-2,709 * * * \\
(2.152) \\
n=1,041\end{array}$ & $\begin{array}{l}-5.250 * * \\
(2.155) \\
n=955\end{array}$ & $\begin{array}{l}-2.815 \\
(2.026) \\
n=955\end{array}$ & $\begin{array}{l}-.277 \\
(.280) \\
n=1,210\end{array}$ & $\begin{array}{l}-.190 \\
(.293) \\
n=1,085\end{array}$ & $\begin{array}{l}.257 \\
(.297) \\
n=1,085\end{array}$ \\
\hline
\end{tabular}

Notes:

For highest grade completed and occupational status, cells contain unstandardized OLS coefficients; all other cells contain logistic regression coefficients. Standard errors are in parentheses.

$*$ denotes 1 -tailed $\mathrm{p}<.05, \quad * * \mathrm{p}<.01, \quad * * * \mathrm{p}<.001$

a Zero-order coefficients

b Partial coefficients controlling for SES, number of siblings, family type, age, African American, Hispanic, cultural resources

c Partial coefficients controlling for all variables in b and cognitive skill, educational expectations.

Furthermore, there is no discernible impact of delinquency on female unemployment. No delinquency variable is significant in any of the three models for females. Why is this the case, especially in light of the links between male delinquency and unemployment? Unemployment may not represent the same negative status for some women as it does for most men. That is, among males, deviance represents a negative attribute that penalizes them in the job market, with unemployment representing one such penalty. However, given that women are more likely than men to work part-time, being unemployed temporarily for a woman is not necessarily a penalty if she is seeking fulltime employment as an alternative to part-time work. Thus, since short bouts of unemployment for women is not necessarily a negative status, it is not surprising that delinquency is not a predictor of such a status.

Finally, what are the unique effects of the various forms of delinquency on outcomes? Tables 4 and 5 present the full multivariate models that include all background, education and delinquency variables. For these models we present all coefficients in order to highlight the role of delinquency in the broader context of status attainment. 
Starting with the educational outcomes, Table 4 shows that most background measures among males are significant in the expected direction in all models. SES is a typically strong positive effect on educational attainment, while number of siblings often has a significant negative impact. Cultural resources has important positive effects for males, while cognitive skill and educational expectations are strong predictors of educational outcomes, adding a significant boost to r square in the model of highest grade completed (where over $55 \%$ of the variance is explained). ${ }^{6}$ Among females, the same social background and academic variables influence educational outcomes, though among females there are more race effects.

For our purposes, the important effects are those of the delinquency. Perhaps the biggest story in Tables 4 and 5 is that there are fewer significant effects of delinquency. Among both males and females, only two of five delinquency variables have unique effects on educational outcomes, and between both genders, only a single delinquency variable is a significant unique predictor of a single employment outcome. What is happening in these full models is that the overall impact of delinquency is shared among its multiple measures. The five delinquency variables are inter-correlated (ranging from .22 to .52) enough to contribute in similar ways to the variance explained, but are not correlated so much as to create collinearity problems (none of the SPSS diagnostics detected any such difficulties). To investigate this further, we introduced another model specification (tables not shown; available upon request) in which a unitary index of delinquency was constructed from the five existing delinquency variables (each of which was standardized and then summed).

Table 4: Regression Estimates for Educational Outcomes by 1992, Full Models

\begin{tabular}{|c|c|c|c|c|c|c|}
\hline \multirow[b]{2}{*}{ Predictor } & \multicolumn{2}{|c|}{ Highest Grade Completed } & \multicolumn{2}{|c|}{ High School Diploma } & \multicolumn{2}{|c|}{ College Degree } \\
\hline & Male & Female & Male & Female & Male & Female \\
\hline SES & \begin{tabular}{|l}
$.178^{* * * *}$ \\
$(.030)$
\end{tabular} & \begin{tabular}{|l|}
$.217 * * *$ \\
$(.030)$ \\
\end{tabular} & \begin{tabular}{|l|}
$.206 * * *$ \\
$(.085)$ \\
\end{tabular} & $\begin{array}{l}.061^{* *} \\
(.099) \\
\end{array}$ & \begin{tabular}{|l}
$.297 * * *$ \\
$(.058)$
\end{tabular} & \begin{tabular}{|l}
$.362 * * *$ \\
$(.061)$
\end{tabular} \\
\hline Number of Siblings & \begin{tabular}{|l|}
$-.046^{*}$ \\
$(.024)$
\end{tabular} & \begin{tabular}{|l|}
$.041^{*}$ \\
$(.023)$
\end{tabular} & \begin{tabular}{|l|}
.016 \\
$(.052)$ \\
\end{tabular} & \begin{tabular}{|l|}
-.075 \\
$(.057)$
\end{tabular} & $\begin{array}{l}-.079 \\
.054)\end{array}$ & \begin{tabular}{|l}
.047 \\
$(.053)$
\end{tabular} \\
\hline Two-Parent Family & $\begin{array}{l}-.110 \\
(.139)\end{array}$ & $\begin{array}{l}.115 \\
(.133)\end{array}$ & \begin{tabular}{|l|}
.328 \\
$(.300)$
\end{tabular} & $\begin{array}{l}1.109 * * * \\
. .307)\end{array}$ & $\begin{array}{l}.171 \\
(.306)\end{array}$ & $\begin{array}{l}.020 \\
(.283)\end{array}$ \\
\hline Age & \begin{tabular}{|l|}
.007 \\
$(.047)$
\end{tabular} & \begin{tabular}{|l|}
$-.082 *$ \\
$(.046)$
\end{tabular} & \begin{tabular}{|l}
.080 \\
$(.115)$
\end{tabular} & \begin{tabular}{|l}
$.233^{*}$ \\
$(.129)$
\end{tabular} & $\begin{array}{l}-.062 \\
(.095)\end{array}$ & $\begin{array}{l}.030 \\
(.093)\end{array}$ \\
\hline African American & $\begin{array}{l}.245 \\
(.174)\end{array}$ & $\begin{array}{l}.442^{* *} \\
(.171)\end{array}$ & $\begin{array}{l}.592 * \\
(.348)\end{array}$ & $\begin{array}{l}.156 \\
(.378)\end{array}$ & $\begin{array}{c}.020 \\
(.455)\end{array}$ & $\begin{array}{l}.093 \\
(.422)\end{array}$ \\
\hline Hispanic & $\begin{array}{l}-.111 \\
(.213)\end{array}$ & \begin{tabular}{|l|}
$.346 *$ \\
$(.195)$
\end{tabular} & \begin{tabular}{|l|}
-.237 \\
$(.427)$
\end{tabular} & \begin{tabular}{|l|}
.148 \\
$(.427)$
\end{tabular} & $\begin{array}{l}.011 \\
(.505)\end{array}$ & $\begin{array}{l}-.135 \\
(.481)\end{array}$ \\
\hline Cultural Resources & \begin{tabular}{|l|}
$.187 * *$ \\
$.062)$
\end{tabular} & $\begin{array}{l}.018 \\
(.062)\end{array}$ & \begin{tabular}{|l|}
.169 \\
$(.131)$
\end{tabular} & \begin{tabular}{|l|}
-.039 \\
$(.154)$
\end{tabular} & $\begin{array}{l}.368 * * \\
(.152)\end{array}$ & $\begin{array}{l}-.277 \\
(.138)\end{array}$ \\
\hline Skipped School & \begin{tabular}{|l|}
$-.146 * *$ \\
$(.037)$
\end{tabular} & $\begin{array}{l}.070 * \\
(.039)\end{array}$ & \begin{tabular}{|l}
$-.247 * * *$ \\
$(.080)$
\end{tabular} & \begin{tabular}{|l|}
$-.254 * *$ \\
$(.093)$ \\
\end{tabular} & $\begin{array}{l}-.145^{*} \\
(.086)\end{array}$ & \begin{tabular}{|l}
-.128 \\
$(0.89)$
\end{tabular} \\
\hline
\end{tabular}


Yesterday's Rebels

\begin{tabular}{|c|c|c|c|c|c|c|}
\hline Drugs & $\begin{array}{l}-.048 * * \\
(.020)\end{array}$ & $\begin{array}{l}-.041 * \\
(.019)\end{array}$ & $\begin{array}{l}-.054 \\
(.046)\end{array}$ & $\begin{array}{l}-.015 \\
(.052)\end{array}$ & $\begin{array}{l}-.064 \\
(.044)\end{array}$ & $\begin{array}{l}-.077 * \\
(.041)\end{array}$ \\
\hline Property Crime & $\begin{array}{l}-.003 \\
(.015)\end{array}$ & $\begin{array}{l}-.007 \\
(.015)\end{array}$ & $\begin{array}{l}-.002 \\
(.033)\end{array}$ & $\begin{array}{l}-.038 \\
(.031)\end{array}$ & $\begin{array}{l}-.032 \\
(.034)\end{array}$ & $\begin{array}{l}-.038 \\
(.040)\end{array}$ \\
\hline Violence & $\begin{array}{l}-.010 \\
(.020)\end{array}$ & $\begin{array}{l}-.005 \\
(.020)\end{array}$ & $\begin{array}{l}.050 \\
(.049)\end{array}$ & $\begin{array}{l}-.022 \\
(.041)\end{array}$ & $\begin{array}{l}-.017 \\
(.042)\end{array}$ & $\begin{array}{l}-.021 \\
(.051)\end{array}$ \\
\hline Contact with criminal justice & $\begin{array}{l}-.171 \\
(.113)\end{array}$ & $\begin{array}{l}-.178 \\
(.166)\end{array}$ & $\begin{array}{l}-.329 \\
(.262)\end{array}$ & $\begin{array}{l}-.393 \\
(.413)\end{array}$ & $\begin{array}{l}-.358 \\
(.244)\end{array}$ & $\begin{array}{l}.265 \\
(.369)\end{array}$ \\
\hline Cognitive skill & $\begin{array}{l}.029 * * * \\
(.002)\end{array}$ & $\begin{array}{l}.032 * * * \\
(.002)\end{array}$ & $\begin{array}{l}.068 * * * \\
(.009)\end{array}$ & $\begin{array}{l}.056 * * * \\
(.010)\end{array}$ & $\begin{array}{l}.039 * * * \\
(.005)\end{array}$ & $\begin{array}{l}.048 * * * \\
(.005)\end{array}$ \\
\hline Educational Expectations & $\begin{array}{l}.323 * * * \\
(.028)\end{array}$ & $\begin{array}{l}.315 * * * \\
(.028)\end{array}$ & $\begin{array}{l}.454^{* * *} \\
(.096)\end{array}$ & $\begin{array}{l}.464^{* * *} \\
(.102)\end{array}$ & $\begin{array}{l}.389 * * * \\
(.057)\end{array}$ & $\begin{array}{l}.343 * * * \\
(.057)\end{array}$ \\
\hline Constant & 7.203 & 6.139 & -6.825 & -.8251 & -9.297 & -7.974 \\
\hline $\mathrm{R}^{2}$ & .556 & .519 & & & & \\
\hline Pseudo R² & & & .406 & .349 & .442 & .419 \\
\hline
\end{tabular}

Notes:

$\mathrm{N}=1,144$ for males; 1,1112 for females. Cells for Highest Grade Completed contain unstandardized OLS regression estimates; all other cells contain logistic regression coefficients; Standard errors are in parentheses

$*$ denotes 1-tailed $\mathrm{p}<.05, \quad * *<.01, \quad * * *<.001$

Results using this omnibus measure of delinquency were essentially identical to those in third models of table 2: delinquency was strongly significant for both male and female educational outcomes and for male occupational outcomes, but not for female occupational outcomes. Given this set of shared effects, Table 5 simply alerts us to "unique" effects, that is, the effects of some delinquency measures independent of related delinquency variables.

These unique effects are as follows. Among males, skipping school has a consistently negative impact on school outcomes, net of all background, educational, and other delinquency variables. Each reported day of skipping reduced attainment by 0.15 years net of all other variables, and reduced the odds ratio of getting a college degree to .865 and of getting a high school diploma to .760. These findings are particularly interesting, given that skipping is arguably the least serious of our measures of delinquency. This suggests that this form of delinquency is a "bad habit" that has autonomously negative effects on educational attainment. Drug use also has important, independent effects on highest grade completed, but not on the other outcomes. Among females, skipping school and drug use each have significant net impacts on two of the three outcomes. The other delinquency variables (contact with criminal justice system, property crime and violence), which were all significant table 2, are reduced to nonsignificance in table 4, for both males and females. It appears that the mildest form of delinquency, skipping school, has the most consistent effects on education because it is the most ubiquitous and common form of deviance across various social categories of youth. It suggests that such youth fare worse in school, over and above their background and academic endowments, and their engagement in other forms of delinquency. 
We turn next to employment outcomes. Table 5 shows that among males, the expected effects of prior educational attainment on both occupational status and unemployment. The r square of .385 suggests that these variables are solid predictors of occupational status, but the smaller pseudo r square [1 - (-2 log likelihood for current model / -2 log likelihood for base model)] for unemployment suggests the latter is more difficult to predict. There is, however, only one direct delinquency effect among males: property crime has a significant independent effect on occupational status. Given the number of significant effects in model 3 of Table 2, this again dramatizes the shared effects of delinquency which are masked by when all delinquency variables are included simultaneously. For females, Table 5 shows similar effects of academic variables on occupational status, but fewer such effects on unemployment. Among delinquency variables, there are no unique effects in either model, which is not surprising given the paucity of significant effects for female occupational status and unemployment in the third models of Table 3 .

Table 5: Regression Estimates for Employment Variables, Full Models

\begin{tabular}{|c|c|c|c|c|}
\hline \multirow[b]{2}{*}{ Predictor } & \multicolumn{2}{|l|}{ Males } & \multicolumn{2}{|l|}{ Females } \\
\hline & $\begin{array}{|lr|}\text { Occupational } & \text { Status } \\
\text { in } & 1992 \\
(\mathrm{~N}=1,029) & \\
\end{array}$ & \begin{tabular}{|l|} 
Unemployed \\
in $\quad 1990$ \\
$(\mathbf{N}=1,053)$
\end{tabular} & $\begin{array}{|lr|}\text { Occupation } & \text { Status } \\
\text { in } & 1992 \\
(\mathrm{~N}-917) & \\
\end{array}$ & $\begin{array}{l}\text { Unemployed } \\
\text { in } 1990 \\
(\mathrm{~N}=1,045)\end{array}$ \\
\hline SES & \begin{tabular}{|l|}
-.078 \\
$(.365)$
\end{tabular} & \begin{tabular}{|l}
-.008 \\
$(.057)$
\end{tabular} & $\begin{array}{l}.-452 \\
(.397)\end{array}$ & $\begin{array}{l}.026 \\
(.058)\end{array}$ \\
\hline Number of Siblings & \begin{tabular}{|l|}
-.283 \\
$(.307)$
\end{tabular} & $\begin{array}{l}.045 \\
(.040)\end{array}$ & \begin{tabular}{|l|}
.130 \\
$(.318)$
\end{tabular} & $\begin{array}{l}-.026 \\
(.043)\end{array}$ \\
\hline Two-Parent Family & \begin{tabular}{|l}
-2.491 \\
$(1.736)$
\end{tabular} & \begin{tabular}{|l|}
.218 \\
$(.234)$
\end{tabular} & \begin{tabular}{|l}
2.339 \\
$(1.763)$
\end{tabular} & $\begin{array}{l}.286 \\
(.233)\end{array}$ \\
\hline Age & \begin{tabular}{|l}
-.803 \\
$(.577)$
\end{tabular} & \begin{tabular}{|l}
$.158^{*}$ \\
$(.084)$
\end{tabular} & \begin{tabular}{|l|}
.397 \\
$(.587)$
\end{tabular} & $\begin{array}{l}-.040 \\
(.083)\end{array}$ \\
\hline African American & $\begin{array}{l}-.283 \\
(2.244)\end{array}$ & \begin{tabular}{|l|}
.105 \\
$(.295)$
\end{tabular} & \begin{tabular}{|l|}
-.939 \\
$(2.304)$
\end{tabular} & $\begin{array}{l}-.351 \\
(.306)\end{array}$ \\
\hline Hispanic & $\begin{array}{l}2.016 \\
(2.679)\end{array}$ & \begin{tabular}{|l|}
.296 \\
$(.353)$
\end{tabular} & $\begin{array}{l}2.854 \\
(2.561)\end{array}$ & $\begin{array}{l}-.179 \\
(.357)\end{array}$ \\
\hline Cultural Resources & \begin{tabular}{|l}
-.090 \\
$(.791)$
\end{tabular} & $\begin{array}{l}-.095 \\
(.107)\end{array}$ & \begin{tabular}{|l|}
-.173 \\
$(.818)$
\end{tabular} & \begin{tabular}{|l}
-.117 \\
$(.110)$
\end{tabular} \\
\hline Skipped School & \begin{tabular}{|l|}
-.529 \\
$(.459)$
\end{tabular} & \begin{tabular}{|l|}
.082 \\
$(.062)$
\end{tabular} & \begin{tabular}{|l|}
-.592 \\
$(.511)$
\end{tabular} & \begin{tabular}{|l}
-.107 \\
$(.073)$
\end{tabular} \\
\hline Drugs & \begin{tabular}{|l|}
.145 \\
$(.245)$ \\
\end{tabular} & $\begin{array}{l}.049 \\
(.033) \\
\end{array}$ & \begin{tabular}{|l|}
-.209 \\
$(.245)$ \\
\end{tabular} & $\begin{array}{l}.046 \\
(.033) \\
\end{array}$ \\
\hline Property Crime & $\begin{array}{l}-.534^{* *} \\
(.188)\end{array}$ & $\begin{array}{l}-.009 \\
(.025)\end{array}$ & $\begin{array}{l}-.140 \\
(.196)\end{array}$ & $\begin{array}{l}.000 \\
(.025)\end{array}$ \\
\hline Violence & \begin{tabular}{|l|}
.223 \\
$(.253)$
\end{tabular} & \begin{tabular}{|l|}
.023 \\
$(.034)$
\end{tabular} & \begin{tabular}{|l|}
.209 \\
$(.273)$
\end{tabular} & $\begin{array}{l}.030 \\
(.033)\end{array}$ \\
\hline $\begin{array}{ll}\text { Contact } & \text { with } \\
\text { criminal justice }\end{array}$ & $\begin{array}{l}-.894 \\
(1.411)\end{array}$ & \begin{tabular}{|l|}
.279 \\
$(.195)$
\end{tabular} & \begin{tabular}{|l}
-2.779 \\
$(2.192)$
\end{tabular} & $\begin{array}{l}-.301 \\
(.315)\end{array}$ \\
\hline
\end{tabular}


Yesterday's Rebels

\begin{tabular}{|c|c|c|c|c|}
\hline Cognitive skill & $\begin{array}{l}175 * * * \\
(.030)\end{array}$ & $\begin{array}{l}-.011 * \\
(.005)\end{array}$ & $\begin{array}{l}.143 * * * \\
(.033)\end{array}$ & $\begin{array}{l}-.012 * * \\
(.005)\end{array}$ \\
\hline Educational Expectations & $\begin{array}{l}1.012 * * \\
(.369)\end{array}$ & $\begin{array}{l}-.153 * * \\
(.054)\end{array}$ & $\begin{array}{l}.298 \\
(.382)\end{array}$ & $\begin{array}{l}.043 \\
(.053)\end{array}$ \\
\hline Highest grade completed & $\begin{array}{l}3.734^{* * *} \\
(.368)\end{array}$ & $\begin{array}{l}-.111 * \\
(.056)\end{array}$ & $\begin{array}{l}2.434^{* * * *} \\
(.388)\end{array}$ & $\begin{array}{l}-.026 \\
(.056)\end{array}$ \\
\hline Constant & -19.015 & 2.547 & -5.001 & -1.26 \\
\hline $\mathrm{R} 2$ & .385 & & .204 & \\
\hline Pseudo $\mathrm{R}^{2}$ & & .065 & & .021 \\
\hline
\end{tabular}

Note:

Cells for Highest Grade Completed contain unstandardized OLS regression estimates; all others contain logistic regression coefficients; Standard errors are in parentheses

$*$ denotes 1-tailed $\mathrm{p}<.05, * *<.01, * * *<.001$

In sum, our investigation yields two main findings. First, among both males and females, all forms of delinquency have consistently negative and significant effects on eventual educational attainment, even controlling for key background and educational variables. Full models suggest that skipping school and drug use have unique impacts on school attainment. Second, there are key gender differences with regard to employment variables. Among males, there are some direct influences of delinquency on unemployment and occupational status controlling for background and education, some indirect influences that are mediated by education variables, and one significant "unique" effect in the full model. Among females, delinquency has some indirect influence on occupational status through its impact on education, but has no direct or unique impact controlling for education. Further, delinquency does not appear to have any influence on female unemployment.

\section{Conclusions}

We know now what happened to yesterday's rebels: according to our evidence, delinquency in adolescence yields a negative dividend and reduces educational and occupational attainments in young adulthood, especially among males. While some social scientists might predict this outcome, and most parents fear it, much of the prior supportive evidence has relied on data from distinctively disenfranchised populations. Our investigation confirms, for the first time, that delinquency reduces the attainments of 'ordinary kids' as well as their more disadvantaged counterparts.

That said, the bigger picture is both more complicated and more qualified because it requires separate considerations of male and female experiences and of different outcomes. For males, almost all forms of adolescent misconduct-from serious violent activity to skipping school - have some consequence for their futures. Some of this status non-attainment stems from the deleterious effects that deviance has upon educational performance, though some is directly attributable to that deviant activity. The educational attainments of young women are also influenced by the indiscretions of their 
youth, but not their occupational outcomes. The latter finding may partly reflect the lesser amount variation in female occupational outcomes to be explained (see Table 1 for the smaller standard deviation of occupational status scores among females versus males), though it likely reflects also the differing roles of employment in male and female lives.

These findings are important for three main reasons. Firstly, they testify to the importance of avoiding trouble when young: early deviance, both directly and indirectly, has lingering effects that negatively influence life chances. Secondly, they illuminate the darker side of subterranean values as practiced by American adolescents; and, in so doing so, cast doubt on the notion of benign or innocuous wrong-doings. That tradition, associated with Matza, argues that involvement in acceptable, if not respectable, teenage culture inoculates adolescents from involvement in more serious delinquency at the same time that it prepares them for conventional adult lifestyles. Our findings do not support this contention, and unlike Hagan, we find no indication that any sub-group of adolescents benefits from an earlier initiation into the risky pleasures of minor delinquency. Perhaps this is because we really are talking about delinquency - not a "party subculture" that only skirmishes with illegalities (as opposed to having a "good time") when drugs are alcohol are factored into the equation.

Third, and perhaps most important, our findings extend efforts to integrate insights from deviancy and stratification research. Many sociologists in the area of status attainment rightly emphasize the distinct impacts on social position of different sources of capital - human, social, and cultural - as well as the more familiar economic determinants. Researchers in this tradition show that the presence or absence of these forms of capital have independent effects upon of the status passage into adult life. While stratification researchers speak to the import of capital in advancing social attainment, theorists of subcultural delinquency and resistance, from Albert Cohen to Paul Willis, in their different ways, emphasize the reverse: that immersion in oppositional working class cultural practices ensure the reproduction of class inequality. However, our findings show that status attainment is stalled, in addition, by participation in delinquent behavior - independent of the amounts and quality of human and cultural capital that delinquents possess.

We do not want to overstate our case here; the distance - temporal and experiential - between delinquency in adolescence and getting a job in young adulthood limits the scope for direct effects of the former on the latter. Just as few students of social stratification (outside strict Marxist orthodoxies) would expect parental social origins to have an unmediated effect upon occupational destinations, few contemporary criminologists would expect that delinquency always or even often to have an unfettered influence upon occupational entry. What is surprising therefore, is not the modesty of the direct effects of delinquency on occupation, but the fact that delinquency has any nonreducible impact upon occupational outcomes at all.

And it is this finding which has the most resonance for the debate referred to earlier on - between those who trace attainments in adult life back to a fundamental 
personality characteristic developed in childhood and those who stress the significance of particular events and situations to which individuals are exposed. Initial appearances to the contrary, these are not necessarily mutually exclusive propositions. In our study, the human resource of "cognitive skill" has the same obdurant generalizing qualities that Gottfredson and Hirschi attribute to the trait of self control: it is the strongest and most consistent predictor of educational and occupational attainments. At the same time, it is also the case that delinquent events can impede and reverse the advantages that cognitive skill bestows upon individuals: thus youthful deviance has a relatively autonomous impact upon life chances.

Just why deviance has this impact is of course another question entirely. What is it exactly about delinquency that impedes progress in the labor market? Is it some relatively stable trait or motivational configuration that is a common source of variation in both legitimate economic activity and illegitimate criminal activity throughout the life course? Or do life-transforming events retard occupational progress regardless of the characteristics of those exposed to them? Delinquency may foster poor work skills, limit social networks, or bring on the effects of labeling and stigmatizing.

Sorting out the relative import of these explanations is obviously the task of future research. We suggest that responses to deviance may have an effect on life course trajectories - a key proposition of labeling theory (Sampson and Laub, 1997). In this argument, contact(s) with the criminal justice system constitutes potential turning points in individual development. Research indicates that adults who are officially identified and processed as criminals will find it harder than other job-seekers to secure employment (Sampson and Laub, 1997; see also Freeman, 1992). It is reasonable to suppose that given a choice, employers will choose to hire those without police records. Similarly, escalating involvements with police, courts and custodial institutions will, in due course, stigmatize and marginalize young people, thereby shrinking their pro-social employment networks, and cut them off from information about conventional jobs (Hagan, 1993). Finally, even if troublesome behavior does not result in official recognition by police and courts, it is likely to generate private conflict with parents and care-givers at home, and more public confrontations with teachers at school. While such disputes might be smoothed over by skillful counseling, it can also be assumed that either, or both of, punitive parenting and authoritarian schooling will engender a negative dividend over time. Needless to say, confirmation of the explanatory power of labeling theory (or some version of it) awaits the demonstration that the stigmatizing and segregating life events provided by the criminal justice system are not simply the spurious artefact of prior and present traits or criminal orientations. Furthermore, if labeling is indeed responsible for turning yesterday's rebels into today's occupational low fliers, we do not know whether it affect all rebels equally, or only those without protection from various forms of capital. These questions await further research. 
Yesterday’s Rebels

\section{Notes}

1. Given the spectacular world-wide success of Learning to Labour - winner of the most citations as an exemplary study in a 1981 survey of British sociologists, and recently credited in Contemporary Sociology and Footnotes as one of the most influential books of the past twenty-five years - it would be intriguing to know what became of Joey, Spanksy and the rest of the 'lads.' Did they end up in, and stay with, working class jobs when they left school? Or did they escape that fate by returning to the educational system? Quite obviously, a proper evaluation of Willis' thesis twenty years on depends upon finding out what eventually happened to the lads. A rumor circulating in British sociology is that Joey, the ring-leader of the lads, did indeed re-enter the chsool system, and is now the proud recipient of a B.A. in English.

2. The contingent and qualified nature of the link between juvenile delinquency and adult crime is well illustrated by the Philadelphia Cohort Study, in which less than $10 \%$ of the non-delinquents had no adult arrest record by age 26, compared with about onethird of the delinquent population (Tracy and Kempf-Leonard, 1997:206). While those findings clearly show that delinquency predicts adult criminality, they also reveal that for the majority of delinquent youth, teen deviancy is not an all-determining harbinger of more serious trouble to come. Moreover, those researchers who identify continuity between juvenile crime and adult crime, or who view adolescent rebellion as a crucial cultural agent in reproducing existing social and economic inequalities, do so by focusing attention upon sites of extreme disadvantage - impoverished inner city neighborhoods - or by targeting members of a reputed underclass (see for example Freedman, 1992). While paying attention to such communities is obviously extremely important, there is also a danger in allowing them to represent the experiences of all adolescents growing up in the United States. Ironically, Sampson and Laub's influential study has been criticized for excluding high risk black youth (Tracy and Kempf-Leonard, 1997:62).

3. Though the delinquency variables are inter-correlated (see the correlation matrix in the Appendix), there do not appear to be any problems of collinearity. The largest correlation between any of the delinquency variables is only .51; the lowest tolerance for any variable, among either males and females, is .51, while the largest variance inflation value was 1.9. None of these indicators suggest any danger of collinearity. This issue is further discussed in the Findings section.

4. We also investigated the possibility of interaction effects by creating a series of product terms between SES and delinquency. However, none of these interaction terms added a significant increment to $\mathrm{r}$ square. While this non-finding may appear on the surface to contrast with Hagan (1991), who found interactions between class background and the effects of subcultural participation on early occupational status, it should be remembered that Hagan's “party subculture”, which had positive effects for middle class males, consisted of leisure activities rather than serious forms of delinquency. 
5. Coefficients actually increase between models one and two for four of the five delinquency variables in the female occupational status regressions. This is because SES is correlated with occupational status, but not delinquency (see Appendix). Thus the inclusion of SES in models thus clarifies the delinquency-occupational status link.

6. Age has effects in some models, but it is likely an artefact of our sample. Since our sample includes only youth still in school, the older students (aged 17 in 1979) would not include among their ranks any high school dropouts. Since few 14 or 15 year olds drop out, the younger cohorts would be less selective, and more representative. This interpretation is supported by the finding that the age coefficients are no longer significant once academic variables are added to the models.

\section{References}

Aschaffenburg, Karen, and Ineke Maas. 1997. "Cultural and Educational Careers: The Dynamics of Social Reproduction.” American Sociological Review 62(4): 573587.

Alexander, Karl, L, Doris, R. Entwisle, and Carrie S. Horsey. 1997. "From First Grade Forward: Early Foundations of High School Dropout.” Sociology of Education 70(2):87-107.

Bourdieu, Pierre. 1984. Distinction: A Social Critique of the Judgement of Taste. Cambridge: Harvard University Press.

Brown, Phillip. 1987. Schooling Ordinary Kids: Inequality, Unemployment, and the New Vocationalism. London: Tavistock.

Bynner, John and Sheena Ashford, 1992. "Teenage Careers and Leisure Lives: An Analysis of Lifestyles.” Society and Leisure 15(2):499-520.

Chesney-Lind, Meda and Randall Sheldon. 1992. Girls, Delinquency and Juvenile Justice. Belmont, California: Brooks/Cole.

Cohen, Albert K. 1955. Delinquent Boys. The Free Press.

Crutchfield, Robert D. and Pitchford, Susan R. 1997. "Work and Crime: The Effects of Labor Stratification.” Social Forces 76(1):93-118.

Davies, Scott. 1995. "Reproduction and Resistance in Canadian High Schools. An Empirical Examination of the Willis Thesis." British Journal of Sociology 46(4):662-87. 
Davies, Scott. and Neil Guppy. 1997. "Fields of Study, College Selectivity, and Student Inequalities in Higher Education.” Social Forces. 75(4):1417-38.

DiMaggio, Paul 1982. "Cultural Capital and School Success: The Impact of Status Culture Participation on the Grades of U.S. High School Students.” American Sociological Review 47(2): 189-201.

Farkas, George. 1996. Human Capital or Cultural Capital? Boulder: Westview Press.

Farkas, George, P. Grobe, D. Sheehan, and Y. Shuan. 1990. "Cultural Resources and School Success: Gender, Ethnicity and Poverty Groups Within an Urban School District.” American Sociological Review 55:127-42.

Farrington, David. 1977. “The Effects of Public Labeling.” British Journal of Criminology 17:112-125.

Farrington, David. 1992. “Criminal Career research in the United Kingdom.” British Journal of Criminology, Vol. 32, No 4 (autumn) pp. 531-536.

Freeman, Richard B. 1992. "Crime and the Employment of Disadvantaged Youths" p201-237 in George E. Peterson and Wayne Vroman (Eds) Urban Labor Markets and Job Opportunity. Washington, D.C.: The Urban Institute Press.

Frith, Simon. 1985. “The Sociology of Youth.” in Michael Haralabos (ed) Sociology: New Directions. Ormskirk: Causeway Press.

Glueck, Sheldon and Eleanor Glueck. 1950. Unraveling Juvenile Delinquency. Cambridge: Harvard University Press.

Hagan, John. 1991. "Destiny and Drift: Subcultural preferences, status attainments and the risks of youth.” American Sociological Review. 56:567-87.

Hagan, John. 1993. “The Social Embeddedness of Crime and Unemployment.” Criminology. 31(4):465-490.

Hagan, John and Bill McCarthy. 1992. "Street Life and Delinquency.” British Journal of Sociology 43(4):533-61.

Jessor, Richard., John Donovan and Frances. Costa. 1993 Beyond Adolescence: Problem Behaviour and Young Adult Development. New York: Cambridge University Press.

Keane, Carl, A.R. Gillis, and John Hagan. 1989. "Deterrence and Amplification of Juvenile Delinquency by Police Contact: The Importance of Gender and Risk Orientation.” British Journal of Criminology 29:336-352. 
Laub, John. and Robert Sampson. 1994 "Unemployment, Marital Discord, and Deviant Behavior: The Long-term Correlates of Childhood Misbehavior", in Travis Hirschi and Michael Gottfredson (eds.) .1994. The Generality of Deviance. New Brunswick, New Jersey: Transaction Publishers.

Matza, David. 1961.”Juvenile Delinquency and Subterranean Values” (with G. Sykes) American Sociological Review 26: 712-29.

MacLeod, Jay. 1995. Ain’t No Makin' It: Leveled Aspirations in a Low-Income Neighborhood (2nd Ed.) Boulder, Colo: Westview Press.

McCarthy, Bill and John Hagan. 1992. "Mean Streets: The Theoretical Significance of Situational Delinquency Among Homeless Youths." American Journal of Sociology 98(3):597-627.

Mensch, Barbara S and Dianne Kandel, 1988. "Dropping out of High School and Drug Involvement.” Sociology of Education. 61(2)95-113.

Monahan, T. 1970. "Police Dispositions of Juvenile Offenders.” Phyhon 31:91-107.

Monk-Turner, Elizabeth. 1989. "Effects of High School Delinquency on Educational Attainment and Adult Occupational Status,” Sociological Perspectives. 33 (1) $413-418$

Murdock, Graham. 1982. "Mass Communication and Social Violence.” in Peter Marsh and Ann Campbell (eds) Aggression and Violence. Oxford: Blackwell.

Myers, David E, Ann M. Milne, Keith Baker, Ann M. Milne, and Alan Ginsburg. 1987. "Student Discipline and High School Performance." Sociology of Education 60(1):18-33.

Polk, Kenneth and Walter Schafer (eds) 1972. School and Delinquency Englewood Cliffs, J.J.: Prentice Hall. 71 -79.

Reiss, Albert. 1960. "Sex Offences: The Marginal Status of the Adolescent.” Law and Contemporary Problems. 25:309-33.

Robins, Lee. 1966. Deviant Children Grow Up. Baltimore: Williams and Wilkins.

Sampson, Robert. and John Laub. 1997 . "A Life-Course Theory of Cumulative Disadvantage and the Stability of Delinquency." p.133-161 in Terence P. Thornberry (ed) Developmental Theories of Crime and Delinquency. Transaction\ Publishers: New Brunswick, USA.

Sampson, Robert. and John Laub. 1993 Crime in the Making: pathways and turning points through life. Cambridge, Ma/London: Harvard University Press. 
Sampson, Robert. and John Laub. 1992 . "Crime and Deviance in the Life Course". Annual Review of Sociology. 18:1 63-84.

Schneider, Barbara and James S. Coleman (eds) 1993. Parents, Their Children, and Schools. Boulder: Westview Press.

Sewell, William and Robert Hauser. 1980. "The Wisconsin Longitudinal Study of Social and Psychological Factors in Aspirations and Achievements." Research in Sociology of Education and Socialization 1:59-99.

Sherman, Lawrence. 1993. "Defiance, Deterrence, and Irrelevance: A Theory of Criminal Sanction,” Journal of Research in Crime and Delinquency. 30 (4) 445-473.

Smith, David. 1995. "Youth Crime and Conduct Disorders: Trends, Patterns and Causal Explanations," pp. 389-489. in Rutter, Michael and David Smith (eds.), Psychological Disorders in Young People: Time Trends and Their Causes. Chichester: John Wiley and Sons.

Stinchcombe, Arthur. 1964. Rebellion in a High School. Chicago: Quadrangle Books.

Teachman, Jay D. 1987. "Family Background, Educational Resources, and Educational Attainment.” American Sociological Review , 52, 548-557.

Tanner, Julian. 1996. Teenage Troubles: Youth and Deviance in Canada. Toronto: Nelson.

Tanner, Julian, Harvey Krahn and Timothy F. Hartnagel. 1995. Fractured Transitions From School to Work: Revisiting the Dropout Problem. Toronto: Oxford University Press.

Willis, Paul. 1977 Learning to Labour. Farnborough: Saxon House, Teakfield. 


\section{Appendix}

\section{Correlations Between all Variables Used in the Analysis (N-2,069 - 2,849)}

\begin{tabular}{|c|c|c|c|c|c|c|c|c|c|c|}
\hline Variable- & (1) & (2) & (3) & (4) & (5) & (6) & (7) & (8) & (9) & (10) \\
\hline \multicolumn{11}{|l|}{ (1) Female } \\
\hline (2) SES & -.029 & & & & & & & & & \\
\hline (3) Siblings & -.035 & $-.268 * *$ & & & & & & & & \\
\hline (4) Family & -.011 & $.102 * *$ & $-.082 * *$ & & & & & & & \\
\hline (5) Age & .030 & $.046^{*}$ & .009 & $.040 *$ & & & & & & \\
\hline (6) Black & .020 & $-.165^{* *}$ & $.193 * *$ & $.2546^{* *}$ & .023 & & & & & \\
\hline (7) Hispanic & .016 & $-269 * *$ & $.121 * *$ & - & -.020 & $-.102 * *$ & & & & \\
\hline (8) Culture & .010 & $.429 * *$ & $.208 * *$ & $.163 * *$ & $.053^{* *}$ & $-.207 * *$ & $-219 * *$ & & & \\
\hline (9) Skipped & $-.041 *$ & $-.055 * *$ & .018 & $-.092 * *$ & $.076 * *$ & $-\overline{-} .068^{* *}$ & .003 & -.001 & & \\
\hline (10) Drugs & .001 & $.086 * *$ & -.020 & -.021 & $.122 * *$ & $-127 * *$ & $-.063 * *$ & $.109 * *$ & $.472 * *$ & \\
\hline (11) Property & .002 & .033 & -.004 & $-.041^{*}$ & $-.042 *$ & -.029 & -.019 & $.061^{* *}$ & $.344 * *$ & $.511 * *$ \\
\hline $\begin{array}{l}\text { (12) Violence - } \\
.001\end{array}$ & $-.057 * *$ & $-.057 * *$ & $.049 *$ & $-.046^{*}$ & - & $.042 *$ & .003 & -.019 & $.271 * *$ & $.320 * *$ \\
\hline (13) Justice & $-258 * *$ & .006 & .028 & $-.046^{*}$ & -.010 & -.032 & -.015 & .021 & $.242 *$ & $.311^{* *}$ \\
\hline (14) Cog. Skill & -.015 & $.503 * *$ & $.250 * *$ & $.154^{* *}$ & $140 * *$ & - $341 * *$ & -.153 & $.400 * *$ & $-\overline{088 * *}$ & .031 \\
\hline $\begin{array}{l}\text { (15) Ed. } \\
\text { Expect. }\end{array}$ & -.015 & $.499 * *$ & $-.156^{* *}$ & $.046^{*}$ & .035 &.$- .046 *$ & -.010 & $.277 * *$ & $\begin{array}{l}- \\
.146^{* *}\end{array}$ & $.087^{*}$ \\
\hline \begin{tabular}{|l|} 
(16) High \\
Grade
\end{tabular} & .022 & $.497 *$ & $-.213 * *$ & $.089 * *$ & $.083 * *$ & $-122 * *$ & $.101^{* *}$ & $.324 * *$ & $-.190 * *$ & $-.096 *$ \\
\hline (17) Diploma & $.057 * *$ & $.230 * *$ & $-.136^{* *}$ & $.116^{* *}$ & $.090 * *$ & $-.063 * *$ & $.098 * *$ & $.223 * *$ & $-.160 * *$ & -.033 \\
\hline (18) Degree & .057 & $.446 * *$ & $-156^{* *}$ & $.082 * *$ & $.041 *$ & $-.136 * *$ & $\begin{array}{l}.077 * * \\
\end{array}$ & $.247 * *$ & $-158 * *$ &. \\
\hline $\begin{array}{l}\text { (19) Occ. } \\
\text { Status . }\end{array}$ & $194^{* *}$ & $.291 * *$ & $-122 * *$ & $.061^{* *}$ & $.055^{* *}$ & $\begin{array}{l}- \\
.126^{* *}\end{array}$ & -.023 & $.200 * *$ & $-102 * *$ & $-.076^{* *}$ \\
\hline (20) Unempld. & -.013 & $-.059 * *$ & $.047 *$ & $-.057 *$ & $-.041^{*}$ & $.050 *$ & .018 & $.076^{* *}$ & $.056 * *$ & $.048^{*}$ \\
\hline
\end{tabular}




\section{Appendix cont'd}

\begin{tabular}{|c|c|c|c|c|c|c|c|c|c|}
\hline Variable & $(11)$ & $(12)$ & $(13)$ & $(14)$ & (15) & (16) & (17) & (18) & (19) \\
\hline \multicolumn{10}{|l|}{ (1) Female } \\
\hline \multicolumn{10}{|l|}{ (2) SES } \\
\hline \multicolumn{10}{|l|}{ (3) Siblings } \\
\hline \multicolumn{10}{|l|}{ (4) Family } \\
\hline \multicolumn{10}{|l|}{ (5) Age } \\
\hline \multicolumn{10}{|l|}{ (6) Black } \\
\hline \multicolumn{10}{|l|}{ (7) Hispanic } \\
\hline \multicolumn{10}{|l|}{ (8) Culture } \\
\hline \multicolumn{10}{|l|}{ (9) Skipped } \\
\hline \multicolumn{10}{|l|}{ (10) Drugs } \\
\hline \multicolumn{10}{|l|}{ (11) Property } \\
\hline (12) Violence & $.487 * *$ & & & & & & & & \\
\hline (13) Justice & $.280^{* *}$ & $.218 * *$ & & & & & & & \\
\hline (14) Cog. Skill & -.005 & $-.134 * *$ & $-.080 * *$ & & & & & & \\
\hline (15) Ed. Expect. & $-.064 * *$ & $-.106 * *$ & $-.129 * *$ & $.509 * *$ & & & & & \\
\hline (16) High Grade & $-.082 * *$ & $-.142 * *$ & $-.133 * *$ & $.623^{* *}$ & $.592 * *$ & & & & \\
\hline (17) Diploma & $-.066^{* *}$ & $-.095 * *$ & $-.119 * *$ & $.352^{* *}$ & $.300 * *$ & $.476^{* *}$ & & & \\
\hline (18) Degree & $-.080 * *$ & $-.125 * *$ & $-.107 * *$ & $.543 * *$ & $.484 * *$ & $.828 * *$ & $.186^{* *}$ & & \\
\hline (19) Occ. Status & $-.084 * *$ & $-.087 * *$ & $-.150 * *$ & $.446 * *$ & $.379 * *$ & $.515 * *$ & $.235 * *$ & $.462 * *$ & \\
\hline (20) Unempld. & .040 & $.053 * *$ & $.044^{*}$ & $-.132 * *$ & $-.096 * *$ & $-.087 * *$ & $-.120 * *$ & $-.062 * *$ & $-.153 * *$ \\
\hline
\end{tabular}

* Denotes correlation is significant at the 0.05 level (2-tailed).

** Denotes correlation is significant at the 0.01 level (2-tailed). 
The Research Network on New Approaches to Lifelong Learning Centre for the Study of Education and Work Ontario Institute for Studies in Education of the University of Toronto (OISE/UT) 252 Bloor Street W, \#12-256, Toronto, ON, M5S 1V6, Canada Tel (416) 923-6641 ext. 2392, Fax (416) 926-4751

E-mail: csew@oise.utoronto.ca 